\title{
Assessing biophysical variable parameters of bean crop with hyperspectral
} measurements

\author{
Priscylla Ferraz Câmara Monteiro ${ }^{1,}$, Rubens Angulo Filho ${ }^{*}$, Alexandre Cândido Xavier², Rodrigo Otávio Câmara Monteiro ${ }^{1, q}$
}

IUSP/ESALQ - Depto. de Engenharia de Biossistemas, C.P. 09 - 13418-900 - Piracicaba, SP - Brasil.

2UFES - Depto. de Engenharia Rural, Alto Universitário, s/n - C.P. 16 - 29500-000 - Alegre, ES - Brasil.

${ }^{*}$ Corresponding author <ruangulo@usp.br>

Edited by: Luís Reynaldo Ferracciú Alleoni

\begin{abstract}
Recently high spectral resolution sensors have been developed, which allow new and more advanced applications in agriculture. Motivated by the increasing importance of hyperspectral remote sensing data, the need for research is important to define optimal wavebands to estimate biophysical parameters of crop. The use of narrow band vegetation indices (VI) derived from hyperspectral measurements acquired by a field spectrometer was evaluated to estimate bean (Phaseolus vulgaris L.) grain yield, plant height and leaf area index (LAI). Field canopy reflectance measurements were acquired at six bean growth stages over 48 plots with four water levels $(179.5 ; 256.5 ; 357.5$ and $406.2 \mathrm{~mm})$ and tree nitrogen rates $(0 ; 80$ and 160 $\mathrm{kg} \mathrm{ha}^{-1}$ ) and four replicates. The following VI was analyzed: OSNBR (optimum simple narrow-band reflectivity); NB_NDVI (narrow-band normalized difference vegetation index) and NDVI (normalized difference index). The vegetation indices investigated (OSNBR, NB_NDVI and NDVI) were efficient to estimate LAl, plant height and grain yield. During all crop development, the best correlations between biophysical variables and spectral variables were observed on V4 (the third trifoliolate leaves were unfolded in $50 \%$ of plants) and R6 (plants developed first flowers in $50 \%$ of plants) stages, according to the variable analyzed.

Keywords: hyperspectral remote sensing, spectroradiometry, vegetation indices
\end{abstract}

Received January 27, 2011

Accepted August 19, 2011 al., 2005; Galvão et al., 2009; Raun et al., 2008; Serrano et al., 2000; Thenkabail et al., 2000).

Hyperspectral remote sensing data has the potential to detect more variations on vegetation than multispectral data, because it uses narrow spectral channels of less than $10 \mathrm{~nm}$ (Stagakis et al., 2010; Thenkabail et al., 2000). These narrow channels allow the detection of detailed features, which could otherwise be disguised by broadband (Schmidt and Skidmore, 2003). Advances in the hyperspectral remote sensing technology are driving the development of new methods to analyze spectral reflectance data. For example, Thenkabail et al. (2000) developed the narrow-band NDVI (NB_NDVI) in which bands are numbered from 1 to 252 allowing several combinations of NB_NDVI for each biophysical variable, such as LAI and yield. Therefore, bean spectral reflectance measurement were analyzed in terms of narrow band vegetation indices (NDVI and NB_NDVI) to estimate biophysical parameters (grain yield, LAI and plant height) at several growth stages during crop cycle and to evaluate the impact of different water levels and $\mathrm{N}$ rates on these biophysical and spectral parameters.

\section{Materials and Methods}

This experiment was conducted at the research farm located in the Piracicaba, São Paulo State, Brazil $\left(22^{\circ} 42^{\prime} 30^{\prime \prime} \mathrm{S}, 47^{\circ} 38^{\prime} 39^{\prime \prime} \mathrm{W}\right)$. The soil of the experimental site was an Oxisol. Chemical properties of soil of the 0-0.2 m-layer (Raij et al., 2001) are the following: $\mathrm{pH}$ 5.3 (in $\mathrm{CaCl}_{2}$ ), K $4.5 \mathrm{mmol}_{\mathrm{c}} \mathrm{dm}^{-3}$, Ca $42 \mathrm{mmol}_{\mathrm{c}} \mathrm{dm}^{-3}$, $\mathrm{Mg} 9 \mathrm{mmol}_{\mathrm{c}} \mathrm{dm}^{-3}, \mathrm{H}+\mathrm{Al} 34 \mathrm{mmol}_{\mathrm{c}} \mathrm{dm}^{-3}, \mathrm{P} 16 \mathrm{mmol}_{\mathrm{c}}$

SUFRGS/FA - Depto. de Plantas Forrageiras e Agrometeorologia, Av. Bento Gonçalves, 7712 - 91540-000 - Porto Alegre, RS - Brasil.

"IFRS - Depto. de Pesquisa e Inovação, Av. Osvaldo Aranha, 540 - 95700-000

- Bento Gonçalves, RS - Brasil. 
$\mathrm{dm}^{-3}$, organic matter $21 \mathrm{~g} \mathrm{dm}^{-3}$ and base saturation 62 $\%$. The granulometric analysis indicated $360 \mathrm{~g} \mathrm{~kg}^{-1}$ clay, $37 \mathrm{~g} \mathrm{~kg}^{-1}$ silt, and $27 \mathrm{~g} \mathrm{~kg}^{-1}$ sand, respectively. Soil bulk density was $1.49 \mathrm{~kg} \mathrm{dm}^{-3}$.

The bean (Phaseolus vulgaris L.) cultivar was "Pérola", variety LR 720982 CPL 53. Bean plants were grown from September to December 2007. According to the Koppen classification, the climate of this region is Cwa (humid and subtropical with dry winters). During the growing season, the mean temperature was $23^{\circ} \mathrm{C}$ and the minimum and maximum temperatures were $16{ }^{\circ} \mathrm{C}$ and 28 ${ }^{\circ} \mathrm{C}$. The effective rainfall during this period was of 168.2 $\mathrm{mm}$. This pattern was close to normal conditions for this region. The water was supplemented with irrigation. Canopy reflectance was collected for each bean plot treated with water depths and $\mathrm{N}$ rates combination.

The experimental design was in randomized blocks with plots subdivided (split-plot design); plots included all four water levels $(179.5 ; 256.5 ; 357.5$ and $406.2 \mathrm{~mm}$ of water, according to Gomes et al., 2000; Guerra et al., 2000; Fancelli and Dourado Neto, 2007), denoted as $W_{1}, W_{2}, W_{3}$ and $W_{4}$ and subplots included three nitrogen rates at 0,80 and $160 \mathrm{~kg} \mathrm{ha}^{-1}$ (Carvalho et al., 2003; Barbosa Filho et al., 2004, 2005), denoted as N0, N1 and N2, respectively, totalizing 12 treatments. Treatments were arranged in four blocks (replications), totalizing 48 experimental plots (Figure 1). Bean was sown on 4 Sep. 2007 with approximately 14 viable seeds per linear meter of row and seedlings emerged on 10 Sep. 2007. Planting rows were oriented north-south and spaced on $0.5 \mathrm{~m}$ with seven rows per plot. Plots were $3.2 \mathrm{~m}$ long and $2.2 \mathrm{~m}$ wide.

Nitrogen fertilizer was ammonium sulfate applied manually and according to the fertilizer recommendations, one third of the total $\mathrm{N}$ dosage was applied in the seeding furrow, and the remaining was top-dressed at two equal rates on 17 Sep. and 6 Oct. 2007, respectively, as sidedressing in a shallow furrow at $0.20 \mathrm{~m}$ from the planting row. Basic fertilization, potassium $(\mathrm{K})$ and phosphorus $(\mathrm{P})$, was done manually on the seeding furrow using $\mathrm{KCl}\left(90 \mathrm{Kg} \mathrm{ha}^{-1} \mathrm{~K}_{2} \mathrm{O}\right)$ and single superphosphate (100 Kg ha-1 $\left.\mathrm{P}_{2} \mathrm{O}_{5}\right)$.

Irrigation was applied using line source sprinkler system, according to Hans et al. (1976). An estimate of crop evapotranspiration was carried out by PenmanMonteith method (Allen et al., 1998) to determine crop water consumption and to compare it with the total amount applied during experimental period, in each water level. The amount of water applied in the initial crop stage was the same for all treatments $(38.3 \mathrm{~mm})$. After 50 DAS, there was a period of approximately 25 days in which there were considerable effective precipitations and therefore there was no need for irrigation.

Final grain yield and plant height were measured at maturity. To eliminate 'edge-effects' a central area of 7.0 $\mathrm{m}^{2}$ was harvested in each plot. Bean grains were ovendried until $16 \%$ humidity was reached (Elias et al., 1999). Three plants per plot were used to estimate the average of final plant height. Non-destructive LAI measurements were performed early in the morning, when there was more diffuse and less direct solar radiation, with a LAI2000 Plant Canopy Analyzer. LAI measurements were made on six dates: 1) 1 Oct. 2007 (V3); 2) 10 Oct. 2007 (V4); 3) 1 Nov. 2007 (R6); 4) 19 Nov. 2007 (R8); 5) 24 Nov. 2007 (R9 - physiological maturity) and 6) 1 Dec. 2007

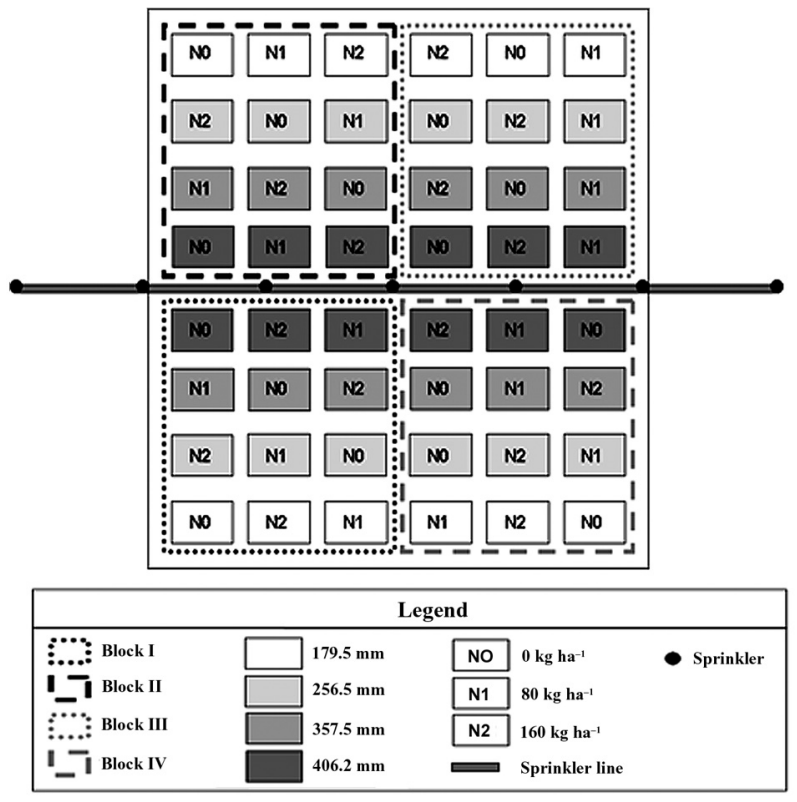

Figure 1 - Experimental area - Piracicaba, SP, 2007.

Table 1 - Radiometric measurements dates, corresponding days after sowing (DAS) and corresponding bean growth stages during experimental period.

\begin{tabular}{lclc}
\hline Date of Measurements & DAS & \multicolumn{1}{c}{ Growth Stage } & Short Name \\
\hline 18 Sep. 2007 & 14 & Plants recent emerged with one leaf & V2 \\
29 Sep. 2007 & 25 & The first trifoliolate leaf unfolded & V3 \\
10 Oct 2007 & 36 & The third trifoliolate leaf unfolded & V4 \\
29 Oct. 2007 & 55 & First flowers developed & R6 \\
18 Nov. 2007 & 75 & Pods with fully developed seeds & R8 \\
23 Nov. 2007 & 80 & $50 \%$ of pods changed colors (physiological maturity) & R9a \\
30 Nov. 2007 & 87 & $80 \%$ of pods changed colors and the leaves fall (harvest maturity) & R9b \\
\hline
\end{tabular}

*The description of all phenological stages is from characteristics observed in $50 \%$ of plants, according to the growth stage description for bean given by Fancelli (2007). 
when (R9 - harvest maturity), according to the growth stage description for bean given by Fancelli (2007).

Radiometric measurements were carried when weather conditions were favorable (Table 1), that is, cloudfree days using the spectron SE-590, as recommended by Moreira et al. (1999). Therefore, measurements were conducted between $11 \mathrm{~h} 00$ and $13 \mathrm{~h} 00$ (local time), the period in which the soil was almost totally illuminated (Jackson et al., 1979), within approximately $2 \mathrm{~h}$ off solar noon, attempting to standardize light conditions.

Remote sensing data consisted of conical-directional reflectance factor spectra collected using SPECTRON SE-590 portable field spectroradiometer, which operates from 350 to $1100 \mathrm{~nm}$ wavelengths of the electromagnetic spectrum. A $15^{\circ}$ IFOV (Instantaneous Field of View) lens was used, positioned at nadir $3 \mathrm{~m}$ above the canopy, maintain a constant height irrespective of the plant growth stage, defining an area of approximately $0.48 \mathrm{~m}^{2}$ above the canopy. Original reflectance data were resampled with a band interval of about 2.7 $\mathrm{nm}$, resulting in 252 bands.

Radiometric measurements were taken using the following protocol: i) for each plot, two pairs of spectrums (sample and reference) were collected, that is, four radiance measurements, two of the canopy and two of the reference plate (barium sulfate), obtaining a reflectance factor in each plot at the end of each reading; ii) the reflectance factor was obtained by the ratio between the spectral radiance of the canopy and the spectral radiance of the reference plate, maintained under the same conditions of illumination and target geometry (Milton, 1987).

Vegetation indices were calculated by reflectance measurements. Three remote sensing techniques were used in this work: i) optimum single narrow-band reflectivity (OSNBR, Thenkabail et al., 2004), ii) narrow-band NDVI (NB_NDVI; Thenkabail et al., 2000), defined as Eq. 1, and, iii) the NDVI described by Daughtry et al. (2000) and Chen et al. (2010), defined as Eq. 2. The OSNBR is that band that presented the best relationship with the biophysical variable analyzed.

NB_NDVI $i j=\frac{N B i-N B j}{N B i+N B j}$;

where $i$ and $j$ are band numbers from 1 to 252 allowing $252 \times 252=63504$ combinations of NB_NDVI for each biophysical variable. Regression coefficients $\mathrm{R}^{2}$ between all possible narrow-bands and biophysical variables were determined using a routine developed with MatLab (MatLab, 2010), that verified for each growth stage the two narrow-band combinations that provided highest $\mathrm{R}^{2}$ values.

$\mathrm{NDVI}=\frac{\rho_{801}-\rho_{670}}{\rho_{801}+\rho_{670}}$

where $\rho 801$ and $\rho 670$ represent the reflectance factors measured at band-center wavelength of $801 \mathrm{~nm}$ and of $670 \mathrm{~nm}$, respectively.

To evaluate the impact of the water levels and $\mathrm{N}$ rates on the biophysical (plant height and grain yield) and vegetation indices (NDVI and NB_NDVI), the statistical procedures were used ANOVA and F test $(p \leq$ 0.05 and $p \leq 0.01)$. The SAS statistical software was used (SAS, 1996). Relationships between the biophysical variables and remote sensing data were done by simple regression analysis. Results were analyzed by means of coefficient of determination $\left(R^{2}\right)$ and p-value.

To improve the precision of the correlations between biophysical and spectral parameters without using assumption for sample distribution, the bootstrapping technique (Efron, 1982) was used with 10,000 random repetitions with replacement (combinations of the 48 plots). The bootstrap statistics consists in the random collection of a predetermined number of samples from a population for $n$ times, yielding $n$ statistic of $\mathrm{R}^{2}$, with the objective of reducing error associated with the collection of a non-representative sample. For each remote sensing VIs and biophysical variable used in this study, the data of the stage that had the highest value of $\mathrm{R}^{2}$ was selected to be compared using bootstrap technique. With those data, the estimative of theirs $95 \%$ bootstrap confidence interval (CI) of $\mathrm{R}^{2}$ were determinate. The procedure steps for bootstrap CI calculation consisted in (Ohtani, 2000; Martinez and Martines, 2008): i) given the data, calculate the statistic $\mathrm{R}^{2}$; ii) bootstrap sample collection and with replacement from original data; iii) calculate the statistic $\mathrm{R}^{2}$ using the bootstrap sample found in step "ii"; iv) repeated steps "b" and "c" (10,000 times); v) the lower and upper endpoint of the confidence interval were given from $(\alpha=0.05)$ quantiles of the bootstrap replicates. To verify if the remote sensing techniques analyzed would have the same ability to estimate the biophysical variables, were constructed the confidence intervals for the difference of bootstrap $\mathrm{R}^{2}$ means were also constructed at 0.95 confidences (Moore and McCabe, 2006). In this analysis, for each remote sensing technique and biophysical variable, the data used in the bootstrap analysis were those regarding the highest $\mathrm{R}^{2}$ values period.

\section{Results and Discussion}

The ANOVA of the biophysical parameters (grain yield, LAI and plant height) values showed that only the water factor affected the mean values. Therefore the relatively large variations observed in these parameters are mainly attributed to different water treatments. No biophysical parameters were affected by $\mathrm{N}$ all analyzed growth stages. This behavior was probably due because the experimental area has gone through a under fallow period by two years and other experiments with legume crops were conducted at this experimental area, so the soil could have a reasonable amount of $\mathrm{N}$ when the bean crop was sown. The low response is expected to nitrogen applied in under fallow soil for two or more 

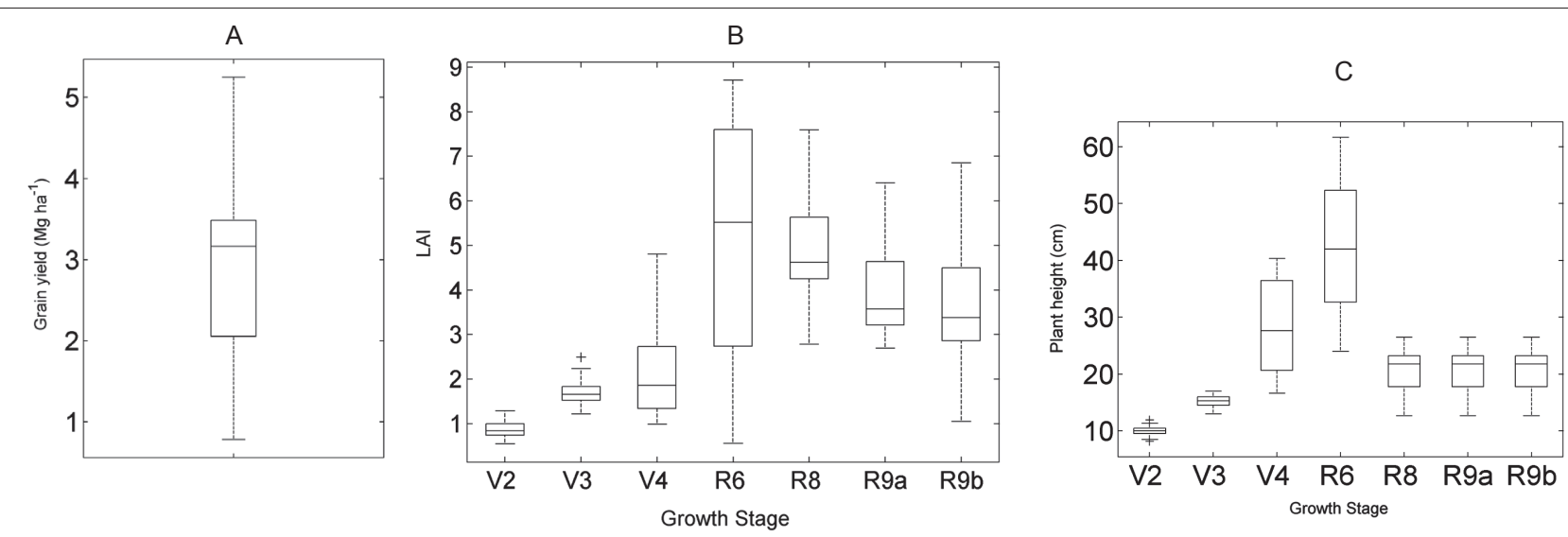

Figure 2 - Boxplot of grain yield (a), LAl (b) and plant height (c) for each growth stage.

years or in soil with a previous legume crop, according to Raij et al. (1997). No interaction between $\mathrm{N}$ and $\mathrm{W}$ for grain yield, LAI and plant height was observed during all bean growth stages.

Figure 2a-c summarizes the bean grain yield, LAI and plant height for each growth stage, respectively. The best correlation coefficient $(r)$ between biophysical variables were observed on stage R6 ( $r=0.85)$ for grain yield, LAI and plant height; between grain yield and plant height on stage R8 $(r=0.80)$; and between LAI and plant height on stage R6 ( $r=0.88)$.

Bean grain yield ranged from $1,004 \mathrm{~kg} \mathrm{ha}^{-1}$ to $3,986 \mathrm{~kg} \mathrm{ha}^{-1}$. Leaf area index (LAI) and plant height ranged from $1.39 \mathrm{~m}^{2} \mathrm{~m}^{-2}$ to $8.30 \mathrm{~m}^{2} \mathrm{~m}^{-2}$, and from 27.25 $\mathrm{cm}$ to $57.4 \mathrm{~cm}$, respectively, on R6 stage (58 DAS) which is a greater vegetative growing stage. These results are similar to those found by Gomes et al. (2000) in which the maximum LAI value was $8.6 \mathrm{~m}^{2} \mathrm{~m}^{-2}$. According to Urchei et al. (2000) the highest values of green leaf area index were at 58 DAS.

Spectral variations among curves are mainly related to differences in crop growth stages (Figure 3). In near infrared wavelengths (NIR; $\lambda \sim 700-950 \mathrm{~nm}$ ), the lowest reflectance values were observed in the early developmental stage (V2), in which there was a smaller amount of green biomass, resulting in reflectance with a lot of influence from the soil and, therefore, the values of reflectance in this stage are lower than in other dates. Maximum reflectance in the NIR was observed in the R8 stage, which has the highest values of green leaf area index, consequently low reflectance of solar radiation in red wavelengths and high scattering of solar radiation in NIR (Jensen, 2007; Moreira et al., 1999). At R9a and R9b stages reflectance in visible (VIS; $\lambda \sim 350-700 \mathrm{~nm}$ ) and NIR regions increase and decrease, respectively, when compared to the previous growth stages, which is mainly caused by the increase of senescent leaves.

The ANOVA of the spectral parameters (NDVI and NB_NDVI) values showed that only the water factor affected the mean values. The $\mathrm{N}$ had no effect on NDVI or NB_NDVI. On the other hand, W treatments affected

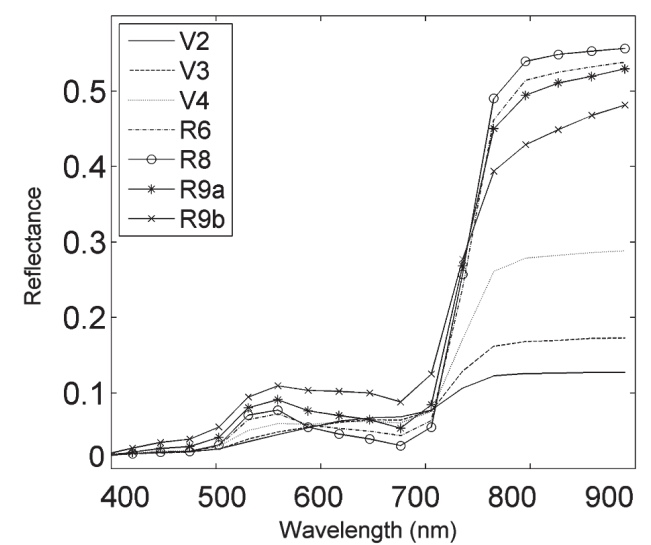

Figure 3 - Spectral reflectance characteristics of bean at distinct growth stages.

these spectral parameters in all analyzed growth stages, excepted on V2 stage. During initial development, plant growth was positively affected by increased W availability, producing more green biomass and LAI (Serrano et al., 2000). Such an increase resulted in larger values of NDVI and NB_NDVI because these features are also sensitive to LAI. Although the most prominent water bands are situated at 1,400 and 1,900 nm (Peñuelas et al., 1997), water stress can be detected by lower development of biomass and consequently a higher percentage of exposed soil which influence canopy spectral properties, confirming previous literature (Gitelson, 2004).

The vegetation indices values increased in the V4 and R6 stage, as expected. This fact might be attributed to the W effect observed during both these stages, predicting a greater LAI. During the R8 and R9 stage, in which bean onset its senescence (Mutanga et al., 2003), the spectral reflectance of bean canopy tends to increase in the red band due to reduce photosynthetic activity of the leaves and decrease in the near infrared range due to reduce multiple scattering (Goel, 1988; Mutanga et al., 2003), which reduced the NDVI and NB_NDVI values. 

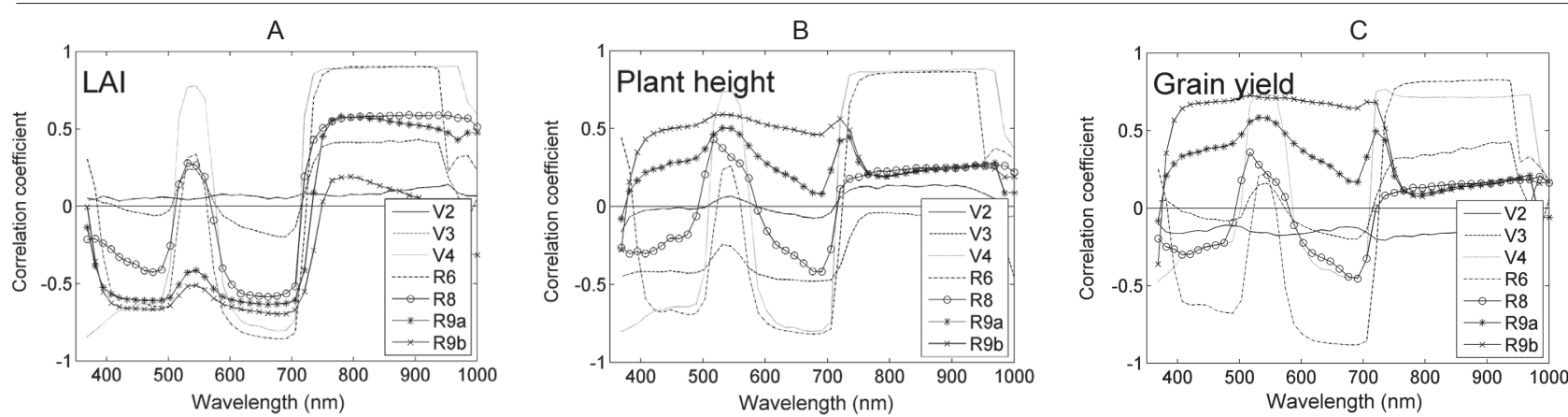

Figure 4 - Correlation coefficients between spectral reflectance of narrow-bands and: (a) LAl; (b) plant height; and (c) grain yield for different growth stages.

The correlation coefficients $(r)$ between each narrow-band and LAI (Figure 4a), plant height (Figure 4b) and grain yield (Figure 4c) at different growth stage are shown in Figure 4. The pattern of $r$ curves for LAI, plant height and grain yield, at different growth stages, were similar, although, $r$ in absolute values for grain yield were smaller than those for LAI and plant height. The greatest positive $r$ values were obtained with reflectance between 740 - $960 \mathrm{~nm}$ wavelengths. Greater positive $r$ for LAI was $0.91(\lambda=950 \mathrm{~nm})$ at V4 stage; for plant height $0.89(\lambda=956 \mathrm{~nm})$ at V4 stage; and for grain yield $0.88(\lambda=915 \mathrm{~nm})$ at R6 stage.

The maximum negative $r$ values were observed at V2 stage as a result of low crop development at this growth stage. Maximum negative $r$ values were observed at R6 stage for all biophysical variables approximately at $680 \mathrm{~nm}$, as observed by Xavier et al. (2006), which correspond to high solar radiation absorption by chlorophyll pigments. For the red-edge region $(\lambda \sim 630-793 \mathrm{~nm})$, a high increase of $r$ values was observed, which correspond to the reflectance increase of vegetation in this region (Figure 2). The best OSNBR for LAI, plant height and grain yield were bands at $950 \mathrm{~nm}\left(\mathrm{R}^{2}=0.83\right), 959 \mathrm{~nm}\left(\mathrm{R}^{2}=\right.$ $0.79)$ and $687 \mathrm{~nm}\left(\mathrm{R}^{2}=0.77\right)$, respectively. Similar results were also observed by Stagakis et al. (2010), Thenkabail (2000), Xavier et al. (2006) and Yang and Chen (2004).

Table 2 summarized the $\mathrm{R}^{2}$ for the relationship between biophysical variables and NB_NDVI and NDVI at different growth stages. In general, greater $\mathrm{R}^{2}$ values were observed at full crop development during V4 and $\mathrm{R} 6$ stages, for all independent variables. The lowest $\mathrm{R}^{2}$ values were observed at V2, V3 and R9b stages, because vegetation was in its initial and senescence stage of development and therefore had a smaller amount of green biomass (Mutanga et al., 2003).

The NB_NDVI and NDVI presented increased $\mathrm{R}^{2}$ values with the development crop and with increasing biomass. Best regression for grain yield $\left(R^{2}=0.84\right)$, LAI $\left(\mathrm{R}^{2}=0.87\right)$ and plant height $\left(\mathrm{R}^{2}=0.87\right)$ were obtained with NB_NDVI index at R6, R6 and V4 stages, respectively (Table 2). The NDVI index explained up to $78 \%$ of LAI variation, up to $82 \%$ of plant height variation and up to $81 \%$ of grain yield variation for R6,
Table 2 - Coefficients of determination $\left(R^{2}\right)$ and wavelength for relationship between biophysical variables (grain yield, LAl and plant height) and NB_NDVI and NDVI indices at different growth stages.

\begin{tabular}{|c|c|c|c|c|}
\hline \multirow{3}{*}{$\begin{array}{l}\text { Dependent } \\
\text { variable }\end{array}$} & \multirow{3}{*}{$\begin{array}{l}\text { Growth } \\
\text { stage }\end{array}$} & \multicolumn{3}{|c|}{ Independent variable } \\
\hline & & \multicolumn{2}{|c|}{ NB_NDVI } & \multirow{2}{*}{$\begin{array}{c}\text { NDVI } \\
\text { Band - 670; } 801 \mathrm{~nm} \\
\mathrm{R}^{2}\end{array}$} \\
\hline & & $\begin{array}{c}\text { Band centers } \\
\mathrm{nm}\end{array}$ & $\mathrm{R}^{2}$ & \\
\hline \multirow{7}{*}{ Grain yield } & V2 & $425 ; 435$ & 0.32 & 0.01 \\
\hline & V3 & $404 ; 433$ & 0.42 & 0.15 \\
\hline & V4 & $762 ; 783$ & 0.63 & 0.54 \\
\hline & R6 & $759 ; 765$ & 0.84 & 0.81 \\
\hline & R8 & $792 ; 823$ & 0.68 & 0.14 \\
\hline & $\mathrm{R} 9 \mathrm{a}$ & $829 ; 839$ & 0.62 & 0.01 \\
\hline & $\mathrm{R} 9 \mathrm{~b}$ & $539 ; 726$ & 0.60 & 0.27 \\
\hline \multirow{7}{*}{ LAl } & V2 & $839 ; 855$ & 0.16 & 0.01 \\
\hline & V3 & $407 ; 469$ & 0.50 & 0.22 \\
\hline & V4 & $611 ; 714$ & 0.83 & 0.77 \\
\hline & R6 & $508 ; 643$ & 0.87 & 0.78 \\
\hline & R8 & $420 ; 942$ & 0.42 & 0.35 \\
\hline & $\mathrm{R9a}$ & $759 ; 783$ & 0.61 & 0.46 \\
\hline & $\mathrm{R} 9 \mathrm{~b}$ & $611 ; 614$ & 0.57 & 0.43 \\
\hline \multirow{7}{*}{ Plant height } & V2 & $469 ; 483$ & 0.28 & 0.03 \\
\hline & V3 & $753 ; 762$ & 0.44 & 0.15 \\
\hline & V4 & $561 ; 732$ & 0.87 & 0.82 \\
\hline & R6 & $593 ; 608$ & 0.81 & 0.68 \\
\hline & $\mathrm{R} 8$ & $533 ; 550$ & 0.57 & 0.13 \\
\hline & R9a & $829 ; 839$ & 0.46 & 0.13 \\
\hline & $\mathrm{R} 9 \mathrm{~b}$ & $792 ; 810$ & 0.40 & 0.12 \\
\hline
\end{tabular}

R9 - a: physiological maturity; R9 - b: harvest maturity; $R^{2}$ - coefficient of determination; *Bold numbers are those that presented highest $\mathrm{R}^{2}$ at each growth stage.

V4 and R6 stages, respectively. Best results were observed for bands in the visible (VIS) region for LAI and plant height and in the near infrared (NIR) region for grain yield. The expectative is that plants with higher production capacity have higher LAI values and consequently higher vegetation indices values.

Figure 5 presents contour plots of the resulting $\mathrm{R}^{2}$ values, plotted diagonally, for grain yield (Figure 5a), LAI (Figure 5b) and plant height (Figure 5c). The stages 

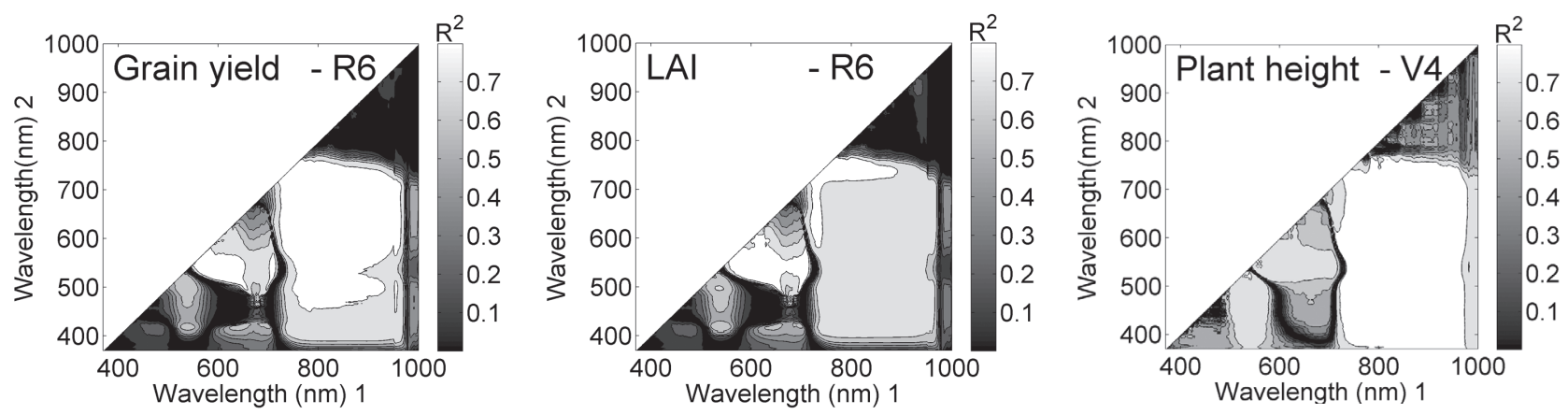

Figure 5 - Contour maps of coefficients of determination $\left(\mathrm{R}^{2}\right) \mathrm{NB} \_$NDVI and grain yield, LAI and plant height.

showed those presented maximum $\mathrm{R}^{2}$ (Table 2). Grey scale legend indicates the class value of $\mathrm{R}^{2}$ between the two-band indices. Bands that showed the greatest potential for estimating biophysical variables at different stages are presented in Table 2 .

The behavior pattern of $\mathrm{R}^{2}$ values for the biophysical variables analyzed are similar to each other and similar to those reported by Thenkabail et al, (2000), that studied crop characteristics including wet biomass, leaf area index, plant height and yield; Gong, et al. (2003) for forest LAI; Stagakis et al. (2010) for LAI. Such behavior is explained by the correlation between the biophysical variables. The highest $\mathrm{R}^{2}$ values are located between 600 and $1200 \mathrm{~nm}$, corresponding spectral region: red region $(\lambda \sim 600 \mathrm{~nm}$ a $\lambda \sim 700 \mathrm{~nm})$, which corresponds to high solar radiation absorption by chlorophyll pigments; rededge region ( $\lambda \sim 705 \mathrm{~nm}$ a $\lambda \sim 735 \mathrm{~nm}$ ), a high reflectance increase, being sensitive to vegetation stress (Thenkabail et al., 2004); and near infrared region, that the high diffuse reflectance from plant leaves is due to the internal scattering at the cell wall-air interfaces within the leaf. These regions includes NIR and VIS indicating the relevance of the combined use of spectral bands from these two regions for vegetation studies (Thenkabail, 2000; 2004) and are used by several sensors such as TM, TM+, HRV e MODIS (Jensen, 2007). Therefore, variables studied in this work can be estimated with high accuracy level from these sensors (Stagakis et al., 2010).

The $\mathrm{R}^{2}$ confidence intervals for the relationships of biophysical variables and VIs were calculated for stages with higher $\mathrm{R}^{2}$ (Table 2 in bold) using bootstrap technique. Figure 6 shows, for each biophysical variable, the confidence interval ranges of $\mathrm{R}^{2}$ calculated using data of NDVI, NB_NDVI and OSNBR with circle, triangle and square symbols, respectively. Although an overlap was observed in the CIs, the means may be different from one another. Taking into account the construction of CI to mean difference of $\mathrm{R}^{2}(95 \%$ bootstrap confidence interval), we can not reject the null hypothesis that the group means are the same, i.e., $\mathrm{R}^{2}$ are not different. Therefore, it is expected that the three vegetation indices have the same potential to estimate the biophysical variables at stages analyzed.

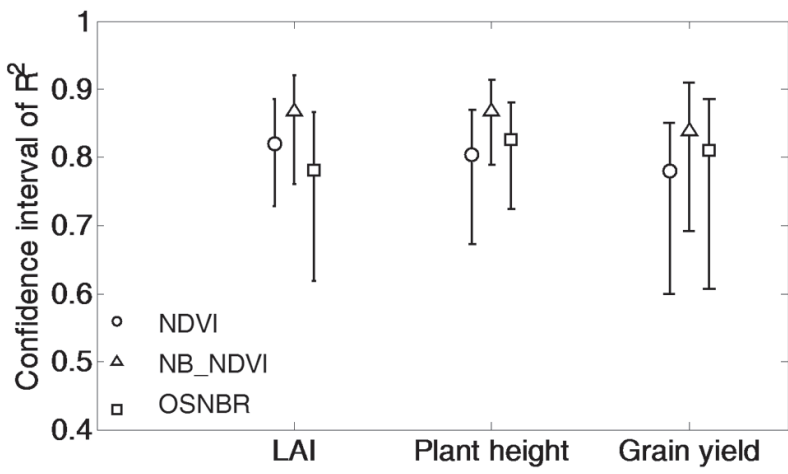

Figure 6 - Correlation coefficients between spectral indices (NDVI; NB_NDVI and simple band) and biophysical variables LAl; plant height; and grain yield.

Hyperspectral vegetation indices OSNBR, NB_ NDVI and NDVI were efficient to estimate bean crop biophysical variables. OSNBR, NB_NDVI, NDVI have the same potential to estimate the biophysical variables. V4 and R6 are the best growth stages to estimate biophysical variables from spectral reflectance measurements and also monitor crop.

\section{References}

Allen, R.G.; Pereira, L.S.; Raes, D.; Smith, M. 1998. 328 p. Crop Evapotranspiration: Guidelines for Computing Crop Water Requirements. FAO, Roma, Italy (FAO Irrigation and Drainage Paper, 56).

Aparicio, N.; Villegas, D.; Casadesus, J.; Araus, J.L.; Royo, C. 2000. Spectral vegetation indices as nondestructive tools for determining durum wheat yield. Agronomy Journal 92: 83-91.

Barbosa Filho, M.P.; Fageria, N.K.; Silva, O.F. 2005. Sources, rates and fractional topdressing of nitrogen fertilizers for irrigated common bean. Ciência e Agrotecnologia 29: 69-76 (in Portuguese, with abstract in English).

Barbosa Filho, M.P.; Fageria, N.K.; Silva, O.F. 2004. Sources and methods of nitrogen fertilizer application in irrigated beans under three levels of soil acidity. Ciência e Agrotecnologia 28: 785-792 (in Portuguese, with abstract in English). 
Carvalho, L.M.; Casali, V.W.D.; Souza, M.A.; Cecon, P.R. 2003. Soil water availability and growth of feverfew. Horticultura Brasileira 21: 726-730 (in Portuguese, with abstract in English).

Chen, P.; Haboudane, D.; Tremblay, N.; Wang, J.; Vigneault, P.; Li, B. 2010. New spectral indicator assessing the efficiency of crop nitrogen treatment in corn and wheat. Remote Sensing of Environment 114: 1987-1997.

Daughtry, C.S.T.; Walthall, C.L.; Kim, M.S.; Colstoun, E.B.; McMurtrey III , J.E. 2000. Estimating corn leaf chlorophyll concentration from leaf and canopy reflectance. Remote Sensing of Environment 74: 229-239.

Efron, B. 1982. The Jackknife, the Bootstrap and Other Resampling Plans. Society for Industrial and Applied Mathematics, Philadelphia, PA, USA.

Eitel, J.U.H.; Long, D.S.; Gessler, P.E.; Hunt, E.R. 2008. Combined spectral index to improve ground-based estimates of nitrogen status in dryland wheat. Agronomy Journal 100: 1694-1702.

Elias, A.I.; Camargo, J.R.O.; Arbex, M. 1999. Mechanized harvest of common bean Phaseolus vulgaris L. p.102-107. In: Fancelli, A.L.; Dourado Neto, D. Irrigated bean crop: basic estrategies management. Publique, Piracicaba, SP, Brazil. (in Portuguese).

Elwadie, M.E.; Pierce, F.J.; Qi, J. 2005. Remote sensing of canopy dynamics and biophysical variables estimation of corn in Michigan. Agronomy Journal 97: 99-105.

Fancelli, A.L. 2007. Bean: Special Topics in Management. Livroceres Piracicaba, SP, Brazil. (in Portuguese).

Fancelli, A.L.; Dourado Neto, D. 2007. Bean Production. Livroceres Piracicaba, SP, Brazil. (in Portuguese).

Galvão, L.S.; Roberts, D.A.; Formaggio, A.R.; Numata, I.; Breunig. F.M. 2009. View

angle effects on the discrimination of soybean varieties and on the relationships between vegetation indices and yield using off-nadir Hyperion data. Remote Sensing of Environment 113: 846-856.

Goel, N.S. 1988. Models of vegetation canopy reflectance and their use in estimation of biophysical parameters from reflectance data. Remote Sensing Reviews 4: 201-212.

Gomes, A.A.; Araújo, A.P.; Rossiello, R.O.P.; Pimentel, C. 2000. Accumulation of biomass, physiological characteristics and grain yield of bean cultivars under irrigated and dry regimes. Pesquisa Agropecuária Brasileira 35: 1927-1937 (in Portuguese, with abstract in English).

Guerra, A.F.; Silva, D.B.; Rodrigues, G.C. 2000. Irrigation timing and nitrogen fertilization for common bean crop in the Cerrado region. Pesquisa Agropecuária Brasileira 35: 12291236 (in Portuguese, with abstract in English).

Gong, P.; Pu, R.; Biging, G.S.; Larrieu, M.R. 2003. Estimation of Forest Leaf Area Index Using Vegetation Indices Derived From Hyperion Hyperspectral Data. IEEE Transactions on Geoscience and Remote Sensing 41: 1355-1362.

Hans, R.J.; Keller, J.; Rasmussen, V.P.; Wilson, G.D. 1976. Line source sprinkler for continuous variable irrigation crop production studies. Soil Science Society of America Journal 40: 426-429.

Jensen, J.R. 2007. Remote Sensing of the Environment: An Earth Resource Perspective. 2.ed. Prentice Hall, Upper Saddle River, NJ, USA.
Jackson, R.D.; Pinter Jr., P.J.; Idso, S.B.; Reginato, R.J. 1979. Wheat spectral reflectance: interactions between crop configuration, sun elevation, and azimuth angle. Applied Optics 18: 37303732 .

Martinez, W.L.; Martinez , A.R. 2008. 792 p. Computational Statistics Handbook with MATLAB. 2.ed. Chapman \& Hall, New York, NY, USA.

Matlab. 2010. Mathworks. Matlab Boston, MA, USA.

Milton, E.J. 1987. Principles of field spectroscopy. International Journal of Remote Sensing 8: 1807-1827.

Moore, D.S.; McCabe, G.P. 2006. Introduction to the Practice of Statistics, 5.ed. W.H. Freeman, New York, NY,USA.

Moreira, M.A.; Angulo Filho, R.; Rudorff, B.F.T. 1999. Radiation use efficiency and harvest index for wheat under drought stress at different growth stages. Scientia Agricola 56: 597603 (in Portuguese, with abstract in English).

Ohtani, K. 2000. Bootstrapping $\mathrm{R}^{2}$ and adjusted $\mathrm{R}^{2}$ in regression analysis. Economic Modelling 17: 473-483.

Peñuelas, J.; Piñol, J.; Ogaya, R.; Fillela, I. 1997. Estimation of plant water concentration by the reflectance water index WI (R900/R970). International Journal of Remote Sensing 18: 2869-2875.

Raij, B. van.; Andrade, J.C.; Cantarella, H.; Quaggio, J.A. 2001. Chemical Analysis for Evaluation of the Fertility of Tropical Soils. Instituto Agronômico, Campinas, SP, Brazil (in Portuguese).

Raij, B. van.; Quaggio, J.A.; Cantarella, H.; Abreu, C.A. 1997. Results interpretation of soil analysis. p. 8-13. In: Raij, B. van.; Cantarella, H.; Quaggio, J.A.; Furlani, A.M.C., ed.. Liming and fertilizer recommendations for São Paulo State. 2.ed. IAC,

Campinas, SP, Brazil. (Boletim Técnico, 100) (in Portuguese).

Raun, W.R.; Solie, J.B.; Taylor, R.K.; Arnall, D.B.; Mack, C.J.; Edmonds, D.E. 2008. Ramp calibration strip technology for determining midseason nitrogen rates in corn and wheat. Agronomy Journal 100: 1088-1093.

Sellers, P.J.; Dickinson, R.E.; Randall, D.A.; Betts, A.K.;Hall, F.G.; Berry, J.A.; Collatz, G.J.; Denning, A.S.; Mooney, H.A.; Nobre, C.A.; Sato, N.; Field, C.B.; Henderson-Sellers, A. 1997. Modeling the exchanges of energy, water, and carbon between continents and the atmosphere. Science 275: 502509.

Serrano, L.; Filella, I.; Penuelas, J. 2000. Remote sensing of biomass and yield of winter wheat under different nitrogen supplies. Crop Science 40: 723-731.

Schmidt, K.S.; Skidmore, A.K. 2003. Spectral discrimination of vegetation types in a coastal wetland. Remote Sensing of Environment 85: 92-108.

Stagakis, S.; Markos, N.; Sykioti, O.; Kyparissis, A. 2010. Monitoring canopy biophysical and biochemical parameters in ecosystem scale using satellite hyperspectral imagery: an application on a Phlomis fruticosa Mediterranean ecosystem using multiangular CHRIS/PROBA observations. Remote Sensing of Environment 114: 977-994.

Thenkabail, P.S.; Smith, R.B.; Pauw, E. 2000. Hyperspectral vegetation indices and their relationships with agricultural crop characteristics. Remote Sensing of Environment 71: 158-182. 
Thenkabail, P.S.; Enclonab, E.A.; Ashtonb, M.S.; Der Meerd, B.V. 2004. Accuracy assessments of hyperspectral waveband performance for vegetation analysis applications. Remote Sensing of Environment 91: 354-376.

Urchei, M.A.; Rodrigues, J.D.; Stone, L.F. 2000. Growth analysis of two bean cultivars under irrigation in no tillage and the conventional tillage. Pesquisa Agropecuária Brasileira 35: 497-506 (in Portuguese, with abstract in English).
Xavier, A.C.; Rudorff , B.F.T.; Moreira, M.A.; Alvarenga, B.S.; Freitas, J.G.; Salomom, M.V. 2006. Hyperspectral field reflectance measurements to estimate wheat grain yield and plant height. Scientia Agricola 63: 130-138.

Yang, C.M.; Chen, R.K. 2004. Modeling rice growth with hyperespectral reflectance data. Crop Science 44: 12831290. 